the leaf. And the longer the pcriod of brewing, the more the extracted soluble substances.

The tea infusions grew stronger liquors by hotter and longer brewing, but the liquor of low grade tea became duller in colour.

As the results of these experiments, the suitable brewing conditions were supposed to be about $90^{\circ} \mathrm{C}$ : : 5 minutes or $100^{\circ} \mathrm{C} .: 2 \sim 3$ minutes.

\title{
茶葉水分の測定についで
}

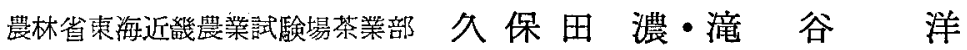

\section{Moisture Measurement of Tea-Leaves}

\section{By Atsushi Kubota and Hiroshi TAkIYA}

\section{1 ま がき}

茶の製造，その他各種の試験を行なうにあたり，茶菜 の水分老測定する機会は非常に多く，その盯定值が試験 結果に及ぼす影響性大さい。さらに茶が加工される過程 反括いて8，水分の存在は重要な役割を果しているの で，加工工程での水分の測定や制缶もりるがせにできな い。また，媻品にとつて水分はその品瞔を左右する重要 な因子であり，水分杖特性汇大なき影響を与える。

以上のように水分の問題は，試験研究，品質管理， るいは品質検定に欠くべらさる重要な䦗題である。し たがつて，水尔を検知しその程度を測定することは，温 度の测定同様あるいは，それ以上に画要なことでするに もかかわらず，測望法，測定精度とも研究が遅れてい る。そこでわれわれ惊茶水分の則管法を改善するため の基杪試験として，主として生葉につき，試料の大きさ により含水率の測定值の变暴係数がどのように恋化する

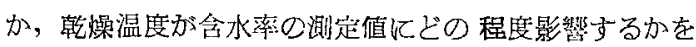
試験したので報告する。なおこの試駼結果を整理するに あたり，鳥井技官に璆町なるで指導をいただいたことを 滐く感謝する。

\section{2 水分測定の基準}

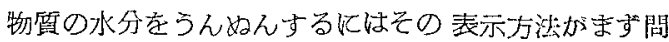

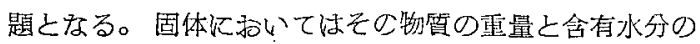
重量との比率が用いられるのが普通で，通常これを会水 率と称している。

いま水分を会んだ試料の重量をW 乾燥したときの重量を $W_{0}$ とすると含水量は $W_{u}-W_{0}$ であり，贪水率は

$$
\mathrm{U}_{w}=\frac{\mathrm{W}_{u}-\mathrm{W}_{0}}{\mathrm{~W}_{u}} \times 100(\%)
$$

あるいは,

$$
\mathrm{U}_{\boldsymbol{d}}=\frac{\mathrm{W}_{u}-\mathrm{W}_{0}}{\mathrm{~W}_{0}} \times 100(\%)
$$

で示される。 $\mathrm{U}_{\boldsymbol{w}}, \mathrm{U}_{\boldsymbol{d}}$ はそれぞれ湿量基準含水率, 乾量

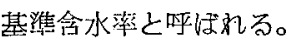

一般汇は湿量基售含水率を用いる場合が多いが，木材 や織物の上う飞乾量基準含水率を用いている場合名西 る。式から明らかなようにU はないが， $\mathrm{U}_{\boldsymbol{a}}$ 将多孔算の物澌では数百\%に達すること もあるので，含水率を諭ずるにはそかが U゙を意味する か， Uw を意味するかを常に念頭におくことが必要です る。畭燥によつて湿潤材料の重量は減少するので，湿量 による基準は落つてくるが，乾量基準は不変である。し たがつて工業的な䛎!算，乾燥機の設計す、゙には後者の疬 うが便利である。たとえば乾燥前後の含水率を添字 1 ， 2 で表わ壮ば，乾量基準含水率の差 $\mathrm{U}_{\boldsymbol{d} 1}-\mathrm{U}_{\boldsymbol{d} 2}$ を無水重 量 $W_{0}$ K乘ずることによつで，直ちに乾燥減量が求めら れるが, 湿量基準の場合は前後の会水率 $\mathrm{U}_{w_{1}}$ と $\mathrm{U}_{w 2}$ との間には共通的な関係がないので，これらの計算を行

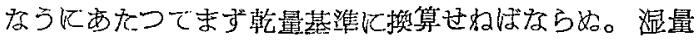

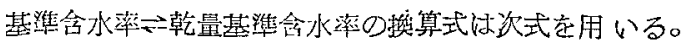

$$
\begin{aligned}
\mathrm{U}_{d} & =\frac{\mathrm{U}_{w}}{1-\mathrm{U}_{w}} \\
\mathrm{U}_{w} & =\frac{\mathrm{U}_{d}}{1+\mathrm{U}_{\boldsymbol{d}}}
\end{aligned}
$$

$\mathrm{U}_{d} ， \mathrm{U}_{w}$ を知るためには $\mathrm{W}_{u} ， \mathrm{~W}_{0}$ を知らねばならな い。合水率の票準的な測定法としては, 初めに Wu 量し，次いで武料を耑温乾燥器中に入れて水分を蒸発さ

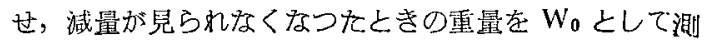

* 茶業技術研究 No. 21，55～59（1959）より転載 
定する方法が採られるが，てのような力法全全乾法と吋。 んでいる。全乾法は水分が常印下 $100^{\circ} \mathrm{C}$ で羔発すること を利用したものであるが，乾燥温度は茶葉のように $100^{\circ} \mathrm{C}$ 以下の值を採つている場合すあるが，凯類は $105^{\circ} \mathrm{C}$ ，木 材社 $100 \sim 105^{\circ} \mathrm{C}$ というように物質によつて多少運つて 規定されている。このような試料は普通揮発成分や酸化 しやすい物質を会んでいるため，重量隇少は水分の蒸発 以外によつても起るからであつて，温度を上げれば揮発 や酸化が堌して含水率注高目比表示され温度を下げれば 水分が蒸発しきれず代含水率は低目に表示される 結果上 なる。場合飞よつては温度 $5^{\circ} \mathrm{C}$ の違い炕るる䛊差は Ud 換算で数\%にも達することがあるので無視できないが， 便宜上，一定温度で蒸発したものをすべて水分と見なし ているわけである。したがつて，票準含水率の測定には てんびんの精度とともれ，定温器内の温度分布之湓度調 節精度が問题とるる。まえ乾燥特間化ついては同一材料 でも個々の乾燥速度にはか子り盖異があり，まて試料の 量も必ずしも一定にできない場合が多く，普通単偟「減 量を見なくなつたとき」と定めてあるが，ての意味㤝重 量減少が表示精度，あるい測定精度に比し無視し得る 状態となつたときを指している。

\section{3 実験方法およひ結果}

\section{1 定温器内の温度分布}

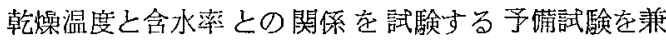
ね，かきまぜ翼のない普通の定温乾燥器の器内温度分布 を調ベた。実験便使用した定温器は内径 $450 \times 400 \mathrm{~mm}$, $600 \mathrm{~W}$ 断綕の電䓡器を有する上下 2 段のものである。上

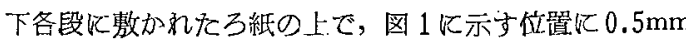

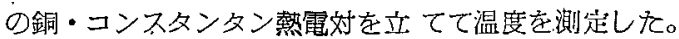
器内温度の䛯節は $1 / 10$ 目盛の水銀温度計を $\times$ 印の個所以，

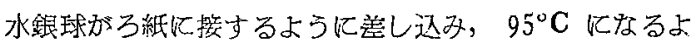
う調節した。温度分布を表 1 に示卞。

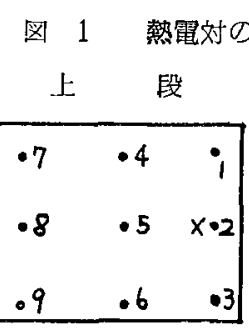

取出口

表 1 温度分布

\begin{tabular}{|c|c|c|c|c|c|c|c|c|c|c|}
\hline 位 & 置 & 1 & 2 & 3 & 4 & 5 & 6 & 7 & 8 & 9 \\
\hline 上 & 段 & 93 & 96 & 89 & 87 & 94 & 91 & 90 & 85 & 82 \\
\hline 下 & 㹂 & 135 & 133 & 116 & 128 & 129 & 116 & 118 & 116 & 108 \\
\hline
\end{tabular}

\section{2 温度亡含水率}

表 1 に見るでとく，定温器内の温度分布注 非常にバラツキが大きい。したがつて温度恙 によつて含水率の表示汇どの程度の美が現わ れるかを訊験した。1958年二番茶の在菜種手 摘菻を用い，試料会水染を垶一化するため乳 ばちですりつぶし，一定量をは心りびん採 り，試料の中心部飞銅・コンスタンタンの䓡 䈱対を差し込み菜温を測定し，試料が恒量に 達するまで乾燥し，茶温之含水率との䦭係を

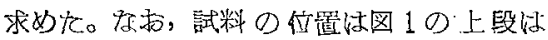
2，4，7，9下弫は7，906所とし， 実験梳覆して行なつた。結果を図 2 に示 す。

\begin{tabular}{|c|c|c|c|c|c|c|c|c|c|}
\hline & & & & 2 & 痛 & 析 & & & \\
\hline \multirow{2}{*}{ 要 } & \multirow{2}{*}{ 因 } & \multicolumn{4}{|c|}{6 月 12 日 } & \multicolumn{4}{|c|}{6 月 21 日 } \\
\hline & & 自由度 & $\begin{array}{l}\text { 偏 } \\
\text { 盖利 } \\
\text { 和 }\end{array}$ & 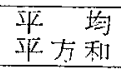 & $F$. & 自由度 & 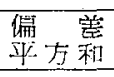 & $\begin{array}{l}\text { 苹 均 } \\
\text { 平方利 }\end{array}$ & $F$ \\
\hline$\hat{\theta}$ & 体 & 5 & 57.43 & & & 5 & 51.54 & & \\
\hline 回 & 膏 & 1 & 42.33 & 42.33 & $11.22 * *$ & 1 & $47 . \dot{4} 5$ & 47.45 & $46.12 * *$ \\
\hline 残 & 莹 & 4 & 15.10 & 3.77 & & 4 & 4.09 & 1.02 & \\
\hline
\end{tabular}

図2茶温と含水率

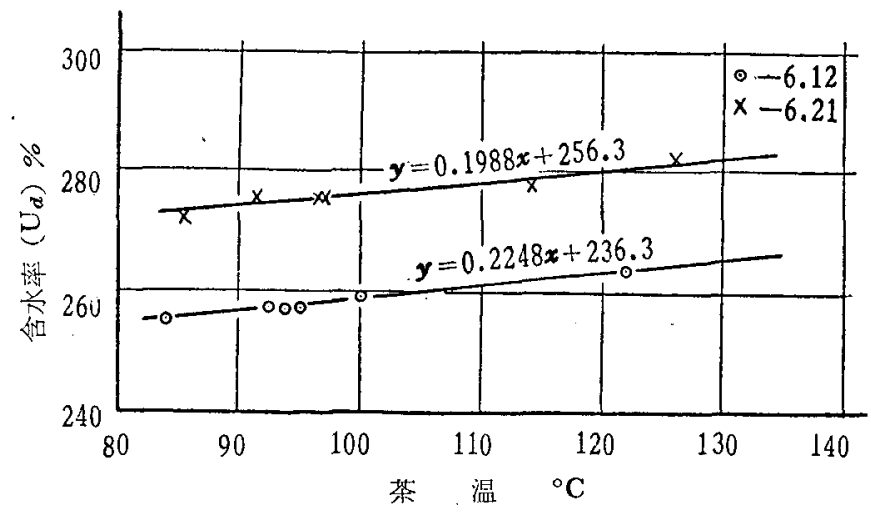




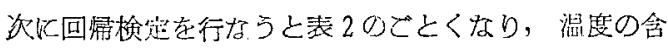

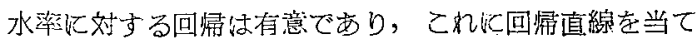
はめると，

$$
\begin{aligned}
& y=0.1988 x+256.3 \cdots \cdots \cdots \cdots 6 \text { 月12日 } \\
& y=0.2248 x+236.3 \cdots \cdots \cdots \cdots 6 \text { 月21日 }
\end{aligned}
$$

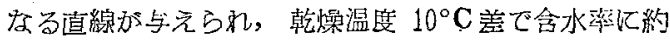
$2 \%$ 恙があつた。

\section{3 試料の量と含水率のバラッキ}

われわれが生葉の含水率を測定与る堎合，含水率の測 定偤に大きなバラツキがあるのが常である。このバラツ

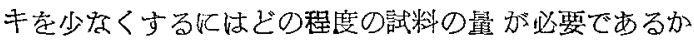
を熱風循還式乾燥器（図 3）を用いて試験した。器内温 度を $95^{\circ} \mathrm{C}$ としたときの温度分布を，図 4 のこととくト下 6 点に銅・コンスタンタンの熱電対を置き測定した。鼬 度話は水銀温度訫を用い，水銀球が下段万紙の上方約 $10 \mathrm{~mm}$ に位置するよう上段を貫通して置いた。結果は表 3に示すでとく温度は活将均一であつた。

\section{図3 定温乾燥器}

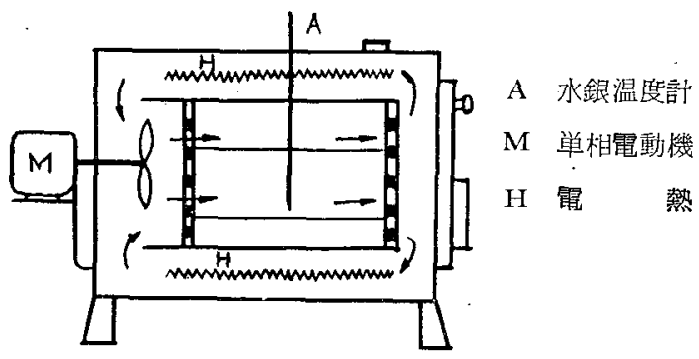

図 4 熱旊対の位置 ( $\times$ 印 水銀温度計)
上段

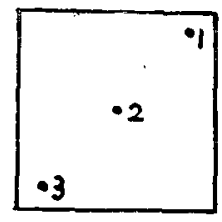

取出口
下段

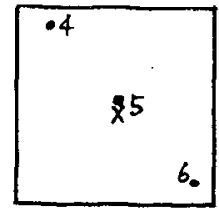

取出口
表 3 温度分布

\begin{tabular}{lc|c|c|c|c|c|c}
\hline 位 & 置 & 1 & 2 & 3 & 4 & 5 & 6 \\
\hline 温 & 度 & 92 & 92 & 92.5 & 93 & 92 & 91.5 \\
\hline
\end{tabular}

訊料は1958年，二鲎茶のはさみ摘生葉・同粗揉葉・手摘 搡机葉・三番茶のはさ夕摘生葉を用い，二番茶生葉に ついては3回，粗揉葉・揉名え葉・三番茶生葉はそれぞ れ 1 回，1959年一香茶のはさ夕摘生葉・同粗揉藮・同搡 视ん葉をとれぞれ 3 回ずつ行なつた。試料性生葉の場合 は, 生葉かでに入つている約 $4 \mathrm{~kg} の$ 中から, 粗揉・揉敞 ん葉はそれぞれ機械から取り出したものを，感量 $0.1 \mathrm{~g}$ の.上皿てんびんでランダム汒 $3 ， 6 ， 10 ， 20 ， 30 \mathrm{~g}$ を椂 り，はかりびんと約 $1.2 \mathrm{~g} の$ の゚ラフィン紙の袋 $(180 \times 120$ Ir m) 飞入れ，器内温度 $95^{\circ} \mathrm{C}$ て恒量飞達するまで乾燥 し,びん感量 $1 \mathrm{mg}$ のてんびん, 袋は感量 $0.1 \mathrm{~g}$ の上西 てんびんで䑁つた。生葉・粗揉・揉ねん葉の含水率和よ

\begin{tabular}{|c|c|c|c|c|c|c|c|c|c|c|c|c|c|c|c|}
\hline \multirow{2}{*}{ 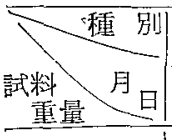 } & \multicolumn{4}{|c|}{ 生 } & \multicolumn{3}{|c|}{ 葉 } & \multicolumn{4}{|c|}{ 粗菉 葉 } & \multicolumn{2}{|c|}{ 搡 ね } & \multicolumn{2}{|c|}{ ん葉 } \\
\hline & $\begin{array}{l}1958 \\
7.7 \\
\end{array}$ & 7.8 & 7.9 & 8.5 & $\begin{array}{r}1959 \\
5.10 \\
\end{array}$ & 5.14 & 5.15 & $\begin{array}{l}1958 \\
7.10 \\
\end{array}$ & $\begin{array}{l}1959 \\
5.10 \\
\end{array}$ & 5.14 & 5.15 & $\begin{array}{l}1958 \\
7.17\end{array}$ & \begin{tabular}{|l}
1959 \\
5.10 \\
\end{tabular} & 5.14 & 5.15 \\
\hline $3 \mathrm{~g}$ & $\begin{array}{l}270 \\
270 \\
290 \\
269\end{array}$ & $\begin{array}{l}386 \\
365 \\
330 \\
373\end{array}$ & $\begin{array}{l}354 \\
334 \\
336 \\
347\end{array}$ & $\begin{array}{l}292 \\
312 \\
301 \\
294\end{array}$ & $\begin{array}{l}273 \\
272 \\
283 \\
274\end{array}$ & $\begin{array}{l}265 \\
264 \\
245 \\
258\end{array}$ & $\begin{array}{l}280 \\
272 \\
273 \\
297\end{array}$ & $\begin{array}{l}147 \\
138 \\
133 \\
137\end{array}$ & $\begin{array}{l}81.4 \\
71.5 \\
84.5 \\
80.9\end{array}$ & $\begin{array}{l}64.9 \\
67.4 \\
66.0 \\
65.2\end{array}$ & $\begin{array}{l}83.5 \\
86.2 \\
86.2 \\
87.8\end{array}$ & $\begin{array}{l}176 \\
175 \\
175 \\
172\end{array}$ & $\begin{array}{l}81.4 \\
85.1 \\
81.2 \\
73.6\end{array}$ & $\begin{array}{l}56.8 \\
59.3 \\
63.5 \\
60.4\end{array}$ & $\begin{array}{l}80.8 \\
84.9 \\
80.3 \\
85.3\end{array}$ \\
\hline $6 \mathrm{~g}$ & $\begin{array}{l}285 \\
270 \\
299 \\
289\end{array}$ & $\begin{array}{l}371 \\
370 \\
366 \\
351\end{array}$ & $\begin{array}{l}342 \\
354 \\
335 \\
341\end{array}$ & $\begin{array}{l}286 \\
279 \\
293 \\
309\end{array}$ & $\begin{array}{l}269 \\
275 \\
335 \\
283\end{array}$ & $\begin{array}{l}248 \\
250 \\
253\end{array}$ & $\begin{array}{l}270 \\
257 \\
278 \\
282\end{array}$ & $\begin{array}{l}139 \\
139 \\
131 \\
142\end{array}$ & $\begin{array}{l}77.9 \\
81.8 \\
77.4 \\
85.8\end{array}$ & $\begin{array}{l}65.0 \\
64.4 \\
67.8 \\
67.8\end{array}$ & $\begin{array}{l}87.2 \\
80.5 \\
84.1 \\
86.2\end{array}$ & $\begin{array}{l}176 \\
175 \\
180 \\
180\end{array}$ & $\begin{array}{l}79.7 \\
82.5 \\
82.1 \\
84.5\end{array}$ & $\begin{array}{l}59.9 \\
60.0 \\
57.3 \\
57.4\end{array}$ & $\begin{array}{l}91.2 \\
85.6 \\
82.3 \\
85.8\end{array}$ \\
\hline $10 \mathrm{~g}$ & $\begin{array}{l}294 \\
287 \\
280 \\
280\end{array}$ & $\begin{array}{l}360 \\
353 \\
347 \\
360 .\end{array}$ & $\begin{array}{l}334 \\
329 \\
333 \\
346\end{array}$ & $\begin{array}{l}302 \\
302 \\
297 \\
300\end{array}$ & $\begin{array}{l}269 \\
305 \\
271 \\
278\end{array}$ & $\begin{array}{l}242 \\
255 \\
252 \\
257\end{array}$ & $\begin{array}{l}271 \\
271 \\
271 \\
278\end{array}$ & $\begin{array}{l}140 \\
140 \\
136 \\
142\end{array}$ & $\begin{array}{l}78.6 \\
76.0 \\
77.4 \\
77.5\end{array}$ & $\begin{array}{l}63.3 \\
62.6 \\
66.0 \\
62.1\end{array}$ & $\begin{array}{l}85.0 \\
89.1 \\
86.4 \\
83.2\end{array}$ & $\begin{array}{l}176 \\
176 \\
179 \\
173\end{array}$ & $\begin{array}{l}82.2 \\
31.6 \\
81.3 \\
82.6\end{array}$ & $\begin{array}{l}62.6 \\
60.3 \\
59.9 \\
60.9\end{array}$ & $\begin{array}{l}80.9 \\
77.6 \\
84.6 \\
81.3\end{array}$ \\
\hline $20 \mathrm{~g}$ & & & $\begin{array}{l}339 \\
346 \\
327 \\
341\end{array}$ & $\begin{array}{l}297 \\
293 \\
287 \\
302\end{array}$ & $\begin{array}{l}278 \\
271 \\
274 \\
269\end{array}$ & $\begin{array}{l}263 \\
234 \\
247 \\
251\end{array}$ & $\begin{array}{l}277 \\
274 \\
281 \\
277\end{array}$ & & $\begin{array}{l}76.8 \\
77.2 \\
76.9 \\
60.8\end{array}$ & $\begin{array}{l}63.7 \\
60.3 \\
64.1 \\
62.4\end{array}$ & $\begin{array}{l}87.3 \\
86.1 \\
84.0 \\
89.7\end{array}$ & $\begin{array}{l}173 \\
173 \\
175 \\
174\end{array}$ & $\begin{array}{l}80.3 \\
81.1 \\
77.6 \\
75.8\end{array}$ & $\begin{array}{l}60.8 \\
60.2 \\
60.4 \\
60.7\end{array}$ & $\begin{array}{l}84.0 \\
85.6 \\
85.0 \\
82.0\end{array}$ \\
\hline 找 $6 \mathrm{~g}$ & & & & $\begin{array}{l}297 \\
295 \\
283 \\
285\end{array}$ & $\begin{array}{l}274 \\
237 \\
300 \\
300\end{array}$ & $\begin{array}{l}243 \\
264 \\
264 \\
243\end{array}$ & $\begin{array}{l}300 \\
287 \\
287 \\
287\end{array}$ & & $\begin{array}{l}76.5 \\
79.2 \\
79.2 \\
.79 .2\end{array}$ & $\begin{array}{l}66.8 \\
64.5 \\
64.5 \\
69.0\end{array}$ & $\begin{array}{l}90.5 \\
93.6 \\
87.5 \\
90.5\end{array}$ & & $\begin{array}{l}79.2 \\
84.6 \\
84.6 \\
79.2\end{array}$ & $\begin{array}{l}62.2 \\
60.0 \\
58.0 \\
58.0\end{array}$ & $\begin{array}{l}90.5 \\
90.5 \\
81.9 \\
90.5\end{array}$ \\
\hline
\end{tabular}

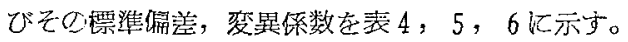

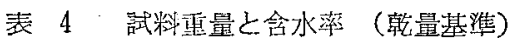




\begin{tabular}{|c|c|c|c|c|c|c|c|c|c|c|c|c|c|c|c|}
\hline \multirow{2}{*}{ 䅜 } & \multicolumn{4}{|c|}{ 生 } & \multicolumn{3}{|c|}{ 葉 } & \multicolumn{4}{|c|}{ 粗 揉 葉 } & \multicolumn{2}{|c|}{ 摄如 } & \multicolumn{2}{|c|}{ 几 葉 } \\
\hline & $\begin{array}{r}1958 \\
7.7 \\
\end{array}$ & 7.8 & 7.9 & 8. 5 & $\begin{array}{l}1959 \\
5.10 \\
\end{array}$ & 5.14 & 5.15 & $\begin{array}{r}1958 \\
7.10 \\
\end{array}$ & $\begin{array}{r}1959 \\
5.10 \\
\end{array}$ & 5.14 & 5.15 & $\begin{array}{l}1958 \\
7.17 \\
\end{array}$ & $\begin{array}{l}1959 \\
5.10 \\
\end{array}$ & 5.14 & 5.15 \\
\hline 玟 $10 \mathrm{~g}$ & & & & $\begin{array}{l}281 \\
303 \\
292 \\
292\end{array}$ & $\begin{array}{l}300 \\
284 \\
271 \\
277\end{array}$ & $\begin{array}{l}256 \\
256 \\
244 \\
270\end{array}$ & $\begin{array}{l}264 \\
284 \\
300 \\
282\end{array}$ & & $\begin{array}{l}81.8 \\
78.6 \\
81.8 \\
85.0\end{array}$ & $\begin{array}{l}65.4 \\
60.0 \\
62.7 \\
62.7\end{array}$ & $\begin{array}{l}88.8 \\
85.2 \\
88.8 \\
85.2\end{array}$ & & $\begin{array}{l}81.8 \\
80.4 \\
85.3 \\
80.3\end{array}$ & $\begin{array}{l}57.5 \\
58.7 \\
57.5 \\
57.5\end{array}$ & $\begin{array}{l}83.5 \\
85.2 \\
83.5 \\
35.2\end{array}$ \\
\hline 戟 $20 \mathrm{~g}$ & $\begin{array}{l}280 \\
270 \\
275 \\
265\end{array}$ & $\begin{array}{l}350 \\
360 \\
355 \\
370\end{array}$ & & $\begin{array}{l}296 \\
291 \\
297 \\
296\end{array}$ & $\begin{array}{l}280 \\
278 \\
281 \\
278\end{array}$ & $\begin{array}{l}251 \\
251 \\
274 \\
248\end{array}$ & $\begin{array}{l}264 \\
267 \\
264 \\
267\end{array}$ & $\begin{array}{l}140 \\
140 \\
140 \\
145\end{array}$ & $\begin{array}{l}81.8 \\
80.2 \\
80.2 \\
78.6\end{array}$ & $\begin{array}{l}62.6 \\
61.3 \\
61.3 \\
60.0\end{array}$ & $\begin{array}{l}88.8 \\
87.8 \\
87.0 \\
87.7\end{array}$ & $\begin{array}{l}180 \\
175 \\
175 \\
175\end{array}$ & $\begin{array}{l}81.8 \\
78.5 \\
80.2 \\
80.2\end{array}$ & $\begin{array}{l}61.2 \\
60.6 \\
61.8\end{array}$ & $\begin{array}{l}82.6 \\
82.6 \\
85.0 \\
84.3\end{array}$ \\
\hline 袋 $30 \mathrm{~g}$ & & & $\begin{array}{l}340 \\
335 \\
340 \\
345\end{array}$ & & $\begin{array}{l}275 \\
273 \\
264 \\
275\end{array}$ & $\begin{array}{l}242 \\
239 \\
242 \\
260\end{array}$ & $\begin{array}{l}257 \\
268 \\
251 \\
262\end{array}$ & & $\begin{array}{l}79.8 \\
78.2 \\
79.2 \\
83.0\end{array}$ & $\begin{array}{l}60.8 \\
61.8 \\
63.6 \\
62.6\end{array}$ & $\begin{array}{l}85.3 \\
91.2 \\
88.8 \\
86.4\end{array}$ & & $\begin{array}{l}80.8 \\
79.8 \\
79.8 \\
77.0\end{array}$ & $\begin{array}{l}60.5 \\
59.7 \\
60.5 \\
62.2\end{array}$ & $\begin{array}{l}83.0 \\
83.4 \\
81.4 \\
83.5\end{array}$ \\
\hline
\end{tabular}

表 5 標 準 偏美 $(S)$ の值

\begin{tabular}{|c|c|c|c|c|c|c|c|c|c|c|c|c|c|c|c|}
\hline \multirow{2}{*}{ 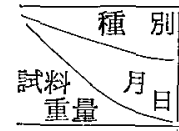 } & \multicolumn{4}{|c|}{ 生 } & \multicolumn{3}{|c|}{ 葉 } & \multicolumn{4}{|c|}{ 粗 ${ }^{\circ}$ 揉 葉 } & \multicolumn{2}{|c|}{ 咏 } & 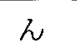 & 葉 \\
\hline & $\begin{array}{l}1958 \\
7.7 \\
\end{array}$ & 7.8 & 7.9 & 8.5 & $\begin{array}{l}1959 \\
5.10 \\
\end{array}$ & 5.14 & 5.15 & $\begin{array}{r}1958 \\
7.10 \\
\end{array}$ & \begin{tabular}{|l|}
1959 \\
5.10 \\
\end{tabular} & 5.14 & 5.15 & $\begin{array}{r}1958 \\
8.5 \\
\end{array}$ & $\begin{array}{l}1959 \\
5.10 \\
\end{array}$ & 5.14 & 5.15 \\
\hline $\begin{array}{r}3 \mathrm{~g} \\
6 \mathrm{~g} \\
10 \mathrm{~g} \\
20 \mathrm{~g}\end{array}$ & $\begin{array}{r}10.08 \\
12.04 \\
6.05\end{array}$ & $\begin{array}{r}23.94 \\
9.26 \\
6.25\end{array}$ & $\begin{array}{l}7.55 \\
7.96 \\
7.32 \\
8.05\end{array}$ & $\begin{array}{r}9.03 \\
12.84 \\
2.39 \\
6.34\end{array}$ & $\begin{array}{l}15.70 \\
30.22 \\
36.62 \\
11.85\end{array}$ & $\begin{array}{r}9.20 \\
2.51 \\
8.96 \\
11.95\end{array}$ & $\begin{array}{r}11.56 \\
11.02 \\
3.50 \\
2.87\end{array}$ & $\begin{array}{l}5.91 \\
4.72 \\
2.52\end{array}$ & $\begin{array}{l}5.61 \\
3.90 \\
1.07 \\
1.92\end{array}$ & $\begin{array}{l}1.12 \\
1.81 \\
1.73 \\
1.71\end{array}$ & $\begin{array}{l}1.78 \\
2.96 \\
2.43\end{array}$ & $\begin{array}{r}9.03 \\
12.84 \\
2.39\end{array}$ & $\begin{array}{l}4.89 \\
1.96 \\
0.19 \\
2.44\end{array}$ & $\begin{array}{l}2.77 \\
1.80 \\
1.19 \\
0.03\end{array}$ & $\begin{array}{l}2.64 \\
3.70 \\
2.86 \\
1.38\end{array}$ \\
\hline 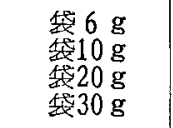 & 6.45 & 9.22 & 4.08 & $\begin{array}{l}7.09 \\
2.50\end{array}$ & $\begin{array}{r}12.44 \\
12.52 \\
1.50 \\
5.25\end{array}$ & $\begin{array}{r}12.10 \\
10.60 \\
12.00 \\
9.60\end{array}$ & $\begin{array}{r}6.50 \\
14.70 \\
1.73 \\
2.28\end{array}$ & 2.06 & $\begin{array}{l}1.34 \\
2.61 \\
1.30 \\
2.07\end{array}$ & $\begin{array}{l}1.91 \\
2.20 \\
1.06 \\
1.16\end{array}$ & $\begin{array}{l}2.49 \\
2.08 \\
0.74 \\
2.62\end{array}$ & $\begin{array}{l}7.09 \\
2.50\end{array}$ & $\begin{array}{l}3.12 \\
2.34 \\
1.34 \\
1.63\end{array}$ & $\begin{array}{l}2.00 \\
0.60 \\
0.60 \\
1.10\end{array}$ & $\begin{array}{l}4.30 \\
0.98 \\
1.22 \\
0.90\end{array}$ \\
\hline
\end{tabular}

表 6 变異续数 (C) \% D值

\begin{tabular}{|c|c|c|c|c|c|c|c|c|c|c|c|c|c|c|c|}
\hline 種 別 & & . & 生 & & 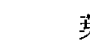 & & & & 期 & 榙 & & ty & da & h & 葉 \\
\hline 料量 月 & $\begin{array}{l}1958 \\
7.7 \\
\end{array}$ & 7.8 & 7. 9 & 8.5 & $\begin{array}{l}1959 \\
5.10 \\
\end{array}$ & 5.14 & 5.15 & $\begin{array}{l}1958 \\
7.10 \\
\end{array}$ & $\begin{array}{l}19.59 \\
5.10 \\
\end{array}$ & 5.14 & 5.15 & $\begin{array}{l}1958 \\
8.5 \\
\end{array}$ & $\begin{array}{r}1959 \\
5.10 \\
\end{array}$ & 5.14 & 5.15 \\
\hline $\begin{array}{r}3 \mathrm{~g} \\
6 \mathrm{~g} \\
10 \mathrm{~g} \\
20 \mathrm{~g}\end{array}$ & $\begin{array}{l}3.71 \\
4.21 \\
2.11\end{array}$ & $\begin{array}{l}6.58 \\
2.54 \\
1.76\end{array}$ & $\begin{array}{l}2.20 \\
2.30 \\
2.18 \\
2.38\end{array}$ & $\begin{array}{l}3.01 \\
4.40 \\
0.79 \\
2.15\end{array}$ & $\begin{array}{r}5.84 \\
10.40 \\
5.91 \\
4.46\end{array}$ & $\begin{array}{l}3.57 \\
1.00 \\
3.56 \\
4.80\end{array}$ & $\begin{array}{l}4.12 \\
4.05 \\
1.28 \\
1.04\end{array}$ & $\begin{array}{l}4.25 \\
3.43 \\
1.80\end{array}$ & $\begin{array}{l}7.05 \\
4.83 \\
1.38 \\
2.46\end{array}$ & $\begin{array}{l}1.70 \\
2.73 \\
2.72 \\
2.73\end{array}$ & $\begin{array}{l}2.06 \\
3.50 \\
2.88 \\
2.78\end{array}$ & $\begin{array}{l}0.99 \\
1.47 \\
1.39 \\
0.55\end{array}$ & $\begin{array}{l}6.08 \\
2.38 \\
0.23 \\
3.10\end{array}$ & $\begin{array}{l}4.61 \\
2.56 \\
1.95 \\
0.49\end{array}$ & $\begin{array}{l}3.18 \\
4.29 \\
3.52 \\
1.63\end{array}$ \\
\hline $\begin{array}{l}\text { 袋 } 6 \mathrm{~g} \\
\text { 袋 } 10 \mathrm{~g} \\
\text { 袋 } 20 \mathrm{~g} \\
\text { 柿 } 30 \mathrm{~g}\end{array}$ & 2.36 & 2.56 & 1.20 & $\begin{array}{l}2.44 \\
0.85\end{array}$ & \begin{tabular}{|l|}
4.28 \\
4.45 \\
0.54 \\
1.93
\end{tabular} & $\begin{array}{l}4.77 \\
4.13 \\
4.68 \\
3.91\end{array}$ & $\begin{array}{l}2.23 \\
5.20 \\
0.65 \\
0.88\end{array}$ & 1.46 & $\begin{array}{l}1.71 \\
3.19 \\
1.62 \\
2.58\end{array}$ & $\begin{array}{l}2.88 \\
3.50 \\
1.72 \\
1.86\end{array}$ & $\begin{array}{l}2.76 \\
2.39 \\
0.84 \\
2.97\end{array}$ & 1.42 & $\begin{array}{l}3.80 \\
2.85 \\
1.67 \\
2.05\end{array}$ & $\begin{array}{l}3.35 \\
1.03 \\
0.98 \\
1.72\end{array}$ & $\begin{array}{l}4.86 \\
1.16 \\
1.45 \\
1.08\end{array}$ \\
\hline
\end{tabular}

表 7 分散 分析表

\begin{tabular}{|c|c|c|c|c|c|c|c|c|c|c|c|c|c|c|c|}
\hline & 種 & 別 & & & 生 & 葉 & & & 粗 & 揉 & & & 揉 好 & 几 葉 & \\
\hline & 要 & 因 & & 首胄 & 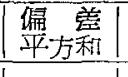 & $\begin{array}{l}\text { 垔均 } \\
\text { 严方和 }\end{array}$ & $F$ & $\begin{array}{l}\text { 自由 } \\
\text { 䓍 } \\
\end{array}$ & 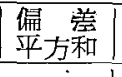 & $\mid \begin{array}{cc}\text { 平 } \text { 均 } \\
\text { 平方和 }\end{array}$ & $F$ & $\begin{array}{l}\text { 自间 } \\
\text { 度 }\end{array}$ & $\mid \begin{array}{ll}\text { 偏 } & \text { 害 } \\
\text { 正和 }\end{array}$ & 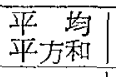 & $F$ \\
\hline $\begin{array}{l}\text { 㝨 } \\
\text { 塾 } \\
\text { 察 }\end{array}$ & $\begin{array}{l}\text { 料 } \\
\text { 驗 }\end{array}$ & $\begin{array}{l}\text { 重 } \\
\text { 回 }\end{array}$ & $\begin{array}{l}\text { 体 } \\
\text { 量 } \\
\text { 器 } \\
\text { 数 }\end{array}$ & $\begin{array}{r}71 \\
2 \\
1 \\
2\end{array}$ & $\begin{array}{r}22747.66 \\
1006.86 \\
506.68 \\
11397.86\end{array}$ & $\begin{array}{r}504.30 \\
506.68 \\
5698.93\end{array}$ & 3.80 & $\begin{array}{r}71 \\
2 \\
1 \\
2\end{array}$ & $\begin{array}{r}7258.54 \\
38.94 \\
14.39 \\
6786.74\end{array}$ & $\begin{array}{r}19.47 \\
14.39 \\
3393.37 \\
\end{array}$ & 2.57 & $\begin{array}{r}71 \\
2 \\
1 \\
2\end{array}$ & $\begin{array}{r}9142.93 \\
33.25 \\
3.92 \\
8707.03\end{array}$ & $\begin{array}{r}16.63 \\
3.92 \\
4353.52\end{array}$ & 3.35 \\
\hline 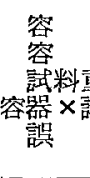 & 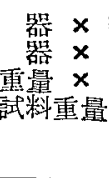 & 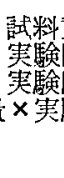 & 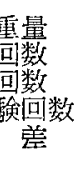 & $\begin{array}{r}2 \\
2 \\
4 \\
4 \\
54\end{array}$ & $\begin{array}{r}51.20 \\
0.37 \\
691.81 \\
1900.51 \\
7192.37\end{array}$ & $\begin{array}{r}25.60 \\
0.185 \\
172.95 \\
475.12 \\
133.19\end{array}$ & & $\begin{array}{r}2 \\
2 \\
4 \\
4 \\
54\end{array}$ & $\begin{array}{r}2.50 \\
26.54 \\
35.51 \\
52.23 \\
301.69\end{array}$ & $\begin{array}{r}1.25 \\
13.27 \\
8.88 \\
13.06 \\
5.58\end{array}$ & & \begin{tabular}{|r|}
2 \\
2 \\
4 \\
4 \\
54
\end{tabular} & $\begin{array}{r}2.84 \\
12.86 \\
171.10 \\
148.52 \\
63.41\end{array}$ & $\begin{array}{r}1.42 \\
6.43 \\
42.77 \\
37.13 \\
1.17\end{array}$ & \\
\hline
\end{tabular}


表によると試料重量の増すことにより，変異係数は小

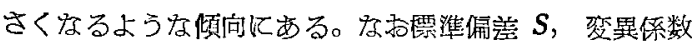
$C(\%)$ の計算式做次式を用いた。

$$
S=\sqrt{\frac{\sum(x i-\bar{x})^{2}}{n}}
$$

$$
C=\frac{S}{\bar{x}} \times 100(\%)
$$

表 7 k生葉, 粗揉葉, 揉少え葉の分散分析を示し，表 8 は訊料重量の恒量洤達するまでの時間を示す。

表 $8 \quad$ 䟼料の恒量に達するまでの時間

\begin{tabular}{cc|c|c|c|c|c|c|c|c} 
重 & 量 & $3 \mathrm{~g}$ & $6 \mathrm{~g}$ & $10 \mathrm{~g}$ & $20 \mathrm{~g}$ & 袋 $6 \mathrm{~g}$ & 袋 $10 \mathrm{~g}$ & $\mathrm{~g}$ \\
\hline 時 & 間 $\mathrm{hr}$ & 5 & 7 & 12 & 14 & 6 & 6 & 6 & 7 \\
\hline
\end{tabular}

\section{4 考察}

以上の結果から生葉の水分を製造恜験を行なう前化測 定する場合，測定の精度よりサンプリングによるバラツ キの俰うが大きく，普通はかりびんで $3 〜 5 \mathrm{~g}$ の跔料を 採るよりも，試料の量老多くする后う加変異係数は小さ くなり，また表 8 の分散分析の結果から，はかりびんと

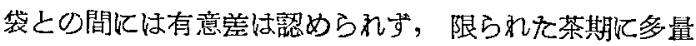
の水分を検定する場合は，はかりびんで測定するよりも 袋で測定する活うが時間的にも早く，経洞的であると思 亏。

茶葉は揉ねんされることにより，ある程度水分が均一 化する傾向にあり，粗搡葉，揉ねん葉などは生葉よりサ ンプリングのバラツキが非常に少なくなる。しかし生葉 亡同様，はかりびんを使用する場合は $10 \mathrm{~g}$ 以上，袋の芘 合にも同様に $10 \mathrm{~g}$ 以上の試料を橓るのがよいと思う。

次飞乾燥温度の影㗽であるが，測定による䛊美は非常 に少ないので無視し，測定值の䛊差 $(\sigma)$ をサンプリング の譔差 $\left(\sigma_{s}\right)$ と乾龽温度による誤差 $\left(\sigma_{d}\right)$ 飞分けると

$$
\sigma=\sigma_{s}+\sigma_{d}
$$

で与えられバラツキの少ない袋20 gの場合でも $s=5$ \%ぐらいは避けられない。の、比し $\sigma_{d}$ が1/5くらいkな るように $\sigma_{d}$ を押えれば，温度の唄差は $\sigma$ に活とんど影

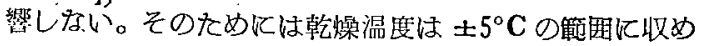
たい。しかし揉灼ん葉，製品の場台にはサンプリングの 誤美が少なくなるから許容乾燥温度はさらに狭めねばな

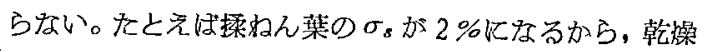

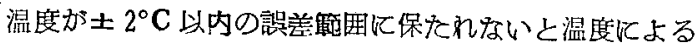
誤差も考虑しないかけ化はゆかなくなる。

\section{5 摘要}

全乾沠により茶葉水分を測定する埸合，乾燥温度が含
水率の指示に及ぼす影響，'サンナ゙ルの大きさと則定值の 变翼係数の関係を調ぺた。

畭燥温度が高くなるに良つて含水率の噂示も直線的に 高くなる。その方向係数は $100^{\circ} \mathrm{C}$ 附近で約 0.2 である。

サンプル量が少ないと測定值のバラツキが 非常に大き くなるので 1 個のサンプル量は少なくとも $10 \mathrm{~g}$ くらいに Lたい。

\section{6 参考 文 献}

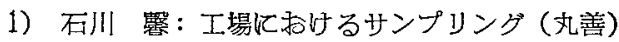
p. 72 (1953).

\section{Summary}

On the moisture measurement of tea leaves, the effect of drying temperature on the observed value of leaf moisture, and the relation between the increment size and the coefficient of variation of moisture level were investigated.

A linear regression was existed between the drying temperature and the observed value of leaf moisture, and its regression coefficient was about 0.2 .

When the increment size was small, the observed value of leaf moisture fluctuated in a wide range, so the increment had to be taken more than $10 \mathrm{~g}$.

(Oct. 13, 1959) 